\title{
A Study of the National Policy on Suppressing Real Estate Speculation: Based on the Comparative Analysis of China, Britain, Singapore and Germany
}

\author{
Quanhong Liu ${ }^{1,2} \quad$ Quanbing Luo ${ }^{1} \quad$ Yayun Xie $^{1}$ \\ 1. School of Business, Jianghan University \\ 2. Manufacturing Industry Development Research Center on the Wuhan City Circle \\ Wuhan, China \\ E-mail: qhliu@163.com_ luoquanbing@qq.com５45101697@qq.com
}

\begin{abstract}
This paper discusses the shortages of the national policy on suppressing real estate speculation based on the comparative analysis of China, Britain, Singapore and Germany, and brings forward corresponding political suggestions Combines the national conditions of our country based on making use of the successful experiences of correlative countries.
\end{abstract}

Key words-real estate; housing price; real estate speculation

\section{INTRODUCTION}

In the 21st century, with the rapid development of industrialization and urbanization, the real estate industry is developing very fast. Chinese real estate industry has become one of the important pillar industries. But in recent years, the real estate market has exposed many problems. The real estate speculation is pushing up the house price, which reasons of the real estate foam.

This paper based on the comparative analysis of China, Britain, Singapore, Germany, discusses the national policy on suppress the real estate speculation, and put forward some suggestions.

\section{The Political Foundation Of Suppressing The REAL Estate SPECULATION}

\section{A. The Definition of Real Estate Speculation}

The real estate speculation refers to the real estate as the transaction object, through the sale, rental and leasing means to use the short term real estate changeful prices to earn high profits behavior. British economists believe that: speculation is when the price or exchange rate change, buying or selling out to earn profits. Therefore, we can not be simply equal to the real estate speculation daily understanding of play the market behavior, and in dealing with the real estate speculation can't simply using general speculative measures.

\section{B. The Political Foundation of Suppressing Real Estate Speculation}

When the real estate develops to a certain extent, the real estate speculation will appear. The real estate speculation exists in the real estate industry for years in all countries, especially the developed one. All countries in the world deal with the real estate speculation, according to their own national characteristics. Throughout these policies, it is not difficult to discover that suppressing the real estate speculation mainly from two aspects, the supply and demand aspect.

\section{1) Supply}

The main way to suppress the real estate speculation is increasing the housing supply and adjusting the supply structure. There are two ways to increase the housing supply, direct and indirect one.

Direct increase of housing supply way is increasing the supply of affordable housing. Singapore increases the group house supply to solve the shortage of housing residents, and prevent overheating in housing price. But Japan through increasing housing and strengthening the housing finance treasury funds to provide for stable prices and suppress the real estate speculation.

Indirect increase housing supply way is to increase the land supply. Hao (2010) argued that, increasing the land supply, especially increasing the supply of residence land, is the key to solve the contradiction between the supply and demand of housing. We have two measures to take action: one is the reasonable planning of urban land use structure; the second is to adjust the layout of land use, encourage industrial project to transfer to the rich resources in west of covering more area.

\section{2) Demand}

On the real estate demand aspect, suppressing the real estate speculation is mainly through taxation, finance, law and policy to increase the cost of speculation, reducing the speculative interest, so as to achieve the purpose of inhibiting the speculative demand.

Britain's real estate speculation atmosphere is not strong, the basic reason is that the British have heavy tax levy in real estate transaction aspect and maintain aspect, which played an important role in suppressing the real estate speculation. But South Korea is mainly by raising capital progressive capital appreciation tax rate to achieve the purpose of inhibiting property speculation.

Take strict precautions against financial excessive support is one of the important measures to suppress speculation and restrain the house prices. On speculative purchase demand, British mainly through improving the loan interest rate, increasing borrowing costs and enlarging the 
pressure of repayment of capital and interest to achieve the purpose of inhibiting the real estate speculation.

Singapore and Germany are the state which typically with laws to guarantee housing and inhibition of real estate market. Singapore has issued a lot of law which as the core of the group house to achieve a standard set of house construction and distribution; Germany regard "residential building law I , II " as the core and add to more than ten department real estate correlation law to achieve the purpose of limiting real estate speculation.

\section{Comparative AnAlysis BASEd On ChinA, BRITAIN, SINGAPORE AND GERMAN}

Contrast foreign country suppressing the real estate speculation policy, we are not difficult to find that: most of the policies and measures are concentrated in the taxation, finance, law and the indemnificatory housing, etc.

\section{A. Tax Policy}

Britain is one of the typically countries to use tax policy to suppress real estate speculation. Britain is mainly setting up a stamp tax and capital value added tax in housing transaction link. British has increased capital value-added tax rates, heritage tax rate and the maximum income tax rates to $40 \%$, in recent years, and also increased real estate tax year by year.

Germany also set up multiple categories of taxes in housing transaction link. In Germany, buying and selling houses must pay tax, real estate tax and spread profit tax. In Germany, the leased building also needs to pay individual income tax, and the tax rate can achieve $45 \%$ of rental income maximum.

Singapore is mainly imposing the seller of the stamp tax, real estate tax and the inheritance tax and the stamp tax levy object is the seller stamp duty which sells the house property in four years to pay for, and the highest rate can reach $16 \%$.

In China, we mainly take difference of tax policies to individual purchase ordinary housing and non common housing, the purchase for the first time and not for the first time, and the impose house property tax has set up a file in the Shanghai, Chongqing and other several city pilot, the tax rate will not more than $2 \%$.

Through the compare, we are not difficult to find that the other three kingdoms in inhibition property speculation tax species are more than in China, and the interest rate is far higher than the level of our country.

\section{B. Financial Policy}

In order to slow the rise in house prices from 2001, the British government enhanced personal mortgage loan interest rate. In a short span of two years, Britain from original mortgage interest rates increased by one point two percent.

German housing financial policy is a "put first and after being credit" contract savings mode. In Germany, savings and loan to buy a house can account for half of the total amount of mortgage loans. The savings and loan combined housing finance model in German has the following benefits:

(1)Provide for low-income families for capital source, and at the same time, the lower loan interest rates also alleviate the pressure of the loan. Low-income people solve the problem of buying houses, which can reduce the space of real estate speculation market

(2)The increase of the demand for buying house contribute to the increase of housing supply, and then drive the housing development of relevant industries.

(3)German is fixed rate system for all mortgage and the savings and loan interest rate are fixed. The long-term mortgage rates can resist any fluctuation in financial markets, which is the key factor of the steady development of the mortgage market.

Singapore's financial housing policy is a bit similar with Germany. Germany acts the savings and loans, but the Singapore acts provident fund loans.

In China, the main measures to suppress the real estate speculation is repeatedly raising deposit reserve rate, improving personal mortgage loan interest rate, and at the same time, reducing the first suite of preferential interest rates. Besides, for the first time, the payment proportion must achieve $30 \%$ of the house, and the secondary buying a house payment proportion must achieve $60 \%$.

Contrast the four countries, we found that the real estate speculation in inhibition financial measures are similar, which belongs to the afterwards controls. Whereas, Singapore and Germany are belong to prior control.

\section{Legal Policy}

In Britain, as far as the single housing act concerned, there are six. Respectively in 1957, 1969, 1974, 1980 and 1988, in the introduction of the housing act. Britain improves the housing act gradually.

In Germany, the real estate related laws are more than ten departments, including "residential building law I , II ", which is the core of the residential construction law. In order to standardize the developers and real estate intermediaries market behavior, Germany also issued a "real estate law, the management method" and "intermediary and development commercial law".

Singapore's houses are divided into two types: group house and commodity house. For security group house and commodity house construction, Singapore also introduced a lot of relevant laws. Singapore's law clear positioning in group house as personal living, and made clear rules on the group of house application, surrender of tenancy and so on.

In China, in order to suppress the real estate speculation, we are taking the main measures on the legal: the ministry of land and resources issued a document related to the land, and making a specific provision including the cultivated land and the area of competitive bidding, auction and 
listing-for-sale, and at the same time they are also in negotiations for idle land treatment method and basic housing security.

Through the contrast we find that, other three kingdoms have residential basic law, except our country, and the real estate legal system relative to the sound and perfect. However, as the real estate development time is shorter than the other three kingdoms.

\section{Indemnificatory Housing}

In order to ease the housing shortage, prevent market speculation, Singapore sticks to give priority to market, supplement by principle, vigorously carry out the group housing scheme.

Singapore's group house is similar to Chinese economy applicable room, Hong Kong's public rental housing, Macao social housing, and the republic of Taiwan's house. In Singapore, not all the residents could apply for the group of house, the law make clear rules Singapore's group housing scheme basically guarantee $80 \%$ of Singapore people can have their own housing.

Britain launches for "partial property right" purchase plan. The government and real estate companies establish a cooperative, which is allowing for half of the building property right owes to the buyers themselves, the rest half by the government, bank share.

Germany's real estate market is very special, the people of renting a house more than buying of it. According to statistics, Germany rental occupancy rate reached 58\%, while its own occupancy rate is only $42 \%$. Germany's developed rental market makes its residents have a stable house to live in. At the same time the German government also provides money for renter subsidies, and let low-income families can also get the appropriate housing.

Our country wants to increase the supply of housing, restrains the real estate speculation has also put forward indemnificatory housing that is affordable housing and low-cost housing, but it does not achieve the desired effect.

Through these four aspects relevant measures, which final suppress the real estate speculation effect on the performance of the four states are different. Britain's housing market price in the long run is going up to fall more than less; Germany's real estate market in recent years develops smoothly; Singapore has $85 \%$ of the residents living in the group of house, and the rest living in commodity house; Chinese real estate market speculation wind is still prevailing, and house prices are still out of people's accepting level.

\section{The Shortage Of Chinese Policy ON SUPPRESSING THE REAL ESTATE SPECULATION}

\section{A. Tax Policy}

Although China implements different tax, its strength is limited. On the tax system, there are lots of loopholes and shortages in our country, the specific is that, in inhibition property speculation aspect, there are not very detailed tax rules in trading links and maintain link, lease, heritage aspects, like Germany and Britain.

\section{B. The Financial Policy}

Our country in dealing with the speculation is mainly to raise the deposit reserve rate, which is through the shrink capital surplus of each big bank to suppress the use of bank capital real estate speculation, but its effect is limited.

Germany and Singapore inhibit property speculation in the financial aspects, which mainly reduce ordinary property buyer loans threshold, so as to solve the problems of low-income people as the starting point. Although China has loan of housing accumulation fund, it needs a lot of time, and the examination and approval procedure is very complex and the application of the eligibility requirements are very strict, therefore, Chinese housing accumulation fund loan system can not serve as main means to solve the problem of low-income people buying house.

\section{Legal System}

China has introduced something about property laws and regulations, but our country housing method in unity, comprehensive aspect still with many problems. Chinese housing legal system is not still enough complete, it can't reach the housing in Germany involved in each subject's corresponding laws and regulations to regulate the market behavior.

\section{Indemnificatory Housing}

In 2010, the central issue of the national is to build 3 million sets of indemnificatory housing construction tasks, the original purpose is ease market for commercial housing demand through increasing the supply of affordable housing, and plays the role in inhibition of the real estate speculation. But since the indemnificatory housing system is not perfect, the policy is not perfect enough to make the indemnificatory housing play its proper role.

\section{The Political Suggestions}

\section{A. Imposing Heavy Tax on the Housing Transaction and Keep}

In the taxation aspects, we can try to collect capital value added tax, when a resident sells the sole apartment, he needn't to pay the capital value added tax, but he need to pay high capital value added taxes if he sell the second ones. For the real estate maintain aspects, we can consider to impose house property tax vacancy. Collection of housing vacancy tax can imitate some countries that rely on property management department and in accordance with the water, electricity, gas using to determine the amount of collection.

\section{B. Regulating Financial System and Taking Financial Innovation}

Regulate financial system and strengthen the supervision of the government to the financial industry, and take the financial innovation is an important means of controlling speculative funds. Regulate financial system mainly display 
that: one is to strengthen the review strength to the real estate lending object; the second is each big bank should be established information sharing system, which can prevent enterprise and individual loan to much people, and more than its loans, to reduce the risk of the bank bad account.

At present, real estate developers, investors, consumers mostly draw support from bank loans, we should carry on the financial innovation, broaden the financing channels of real estate industry, and increase its financing capability.

\section{Consummating Related Legal System}

Our current real estate for special law is mainly the administration of urban real property and the land administration law, so we should take German as reference, and issue law according to the personal and property intermediary.

In addition to introduce new law, in order to make the real estate industry more standard and orderly development, we should constantly improve the administration of urban real property and the land administration law. For property management, real estate transactions, property ownership registration, and housing demolition, we should constantly supplement, revise and better for the continuous development of real estate service industry.

\section{Learning from Foreign Successful Experience, and Improving the System of Affordable Housing}

The main issue of our indemnificatory housing is lack of funds. Singapore solves group housing funds partly through the commodity houses. Singapore doesn't crack down the price of commercial housing, so as to get a considerable income to afford for group housing funds. It is necessary for us to set up the long-term and stable capital investment mechanism if we want to develop indemnificatory housing.

\section{E. Standardizing the Government's Behavior and Avoiding to GDP Fetishism}

One of the important aspects of suppressing speculation is still gradually reduce the dependence for government financial to land.

In order to avoid the local government's blind worship to the GDP achievement, local government should reform achievements evaluation system, as GDP can't represent all, we should bring indemnificatory housing construction, housing price income ratio, house prices rising speed, etc into account.

\section{CONCLUSION}

Whether real estate speculation is effectively restrained is related to its healthy sustainable development of China's real estate market. So the policy of suppressing real estate speculation is unshakable. Otherwise, suppressing real estate speculation can be not accomplished in one move, but it is the first step on the right way to promote our economy rapidly develops.

\section{ACKNOWLEDGMENT}

This paper is supported by Manufacturing Industry Development Research Center in the Wuhan City Circle.

\section{REFERENCES}

[1] Z. Bao, "How does South Korea regulate real estate speculation," Shanghai entrepreneurs, 2008, (5): 50-51.

[2] W. Cheng, "Political Experience and Revelation of Major Countries and Districts,” Journal of macro-economic research, 2010, (3): 22-28.

[3] Y. Hao, China's housing observation and international comparison, 2 edition, Beijing: China Architecture Press, 2010.

[4] G. Li, "The Political Measures and Significance of Foreign Countries' Controlling Property Price Hike,” Journal of consumer guide, 2010, (2): 70-71.

[5] H. Li, "How does British Government Suppress Real Estate Speculation,” China Real Estate Finance, 2011, (5): 44-45.

[6] S. Wang, The Principle and Effective Evaluation of Chinese Government's intervening on Housing Market, Beijing: Tsinghua University Press, 2009.

[7] H. Wu, "A Summary on Public Housing's Financial Policies of Various Countries and the Enlightenments toward Our Country," Commercial economy, 2004, (8): 141-143.

[8] J. Zhou, Financial Excessive Support and Real Estate Bubble Theoretical and Empirical Research, Beijing: Peking University Press, 2005. 